\title{
The Ural-African Transcontinental Oil and Gas Belt
}

\author{
Litvinenko VS and Kozlov AV*
}

Department of Geological and Mineralogical Sciences, University of Mines, Russia

\begin{abstract}
Analysis of geological positions of the largest oil-and-gas-bearing basins, carried out on the basis of research data represented in the "Geological atlas of Russia" and other publications, allowed to mark out petroleum-bearing Ural-African oil and gas belt. This largest on the Earth belt of hydrocarbons accumulation is connected with the near-meridional band of a giant long-existing intercontinental faulting (rifting) zone preexistent since Riphean in the central part of Eurasia and elongated with smooth rejuvenation through Paleozoic and Mesozoic into the South Caspian region, Persian gulf and into African platform (meridian system of African rifts). Most part of conventional oil (near $75 \%$ ) and gas (more than $65 \%$ ) reserves are concentrated within the bounds of this belt. The area of this unique "saturated-in-hydrocarbons" structure makes only 6-7\% of the total globe surface. By its geological structure and character of the mantle and crust masses differentiation, this belt features the global anomaly zone in the Earth gravitation field.

Large part of the Ural-African transcontinental petroleum belt (>50\% of area) occurs on the territory of Russia Its northern part comprises principal Russian oil-and-gas-bearing basins comprising most of large and super-large hydrocarbon fields which contain predominant amount of explored in Russia reserves of oil (95\%) and gas (>95\%). By the thickness and area size of sedimentary cover, as well as the quantity of explored natural gas resources, the West-Siberian basin is quite similar to the Persian Gulf significantly receding only in oil reserves (8 times less). Taking into account a certain parity of oil and gas ratio in principal petroleum basins of the world, the revealed oil-gas disproportion in West Siberia may be considered as an argument for high probability of new discoveries of oil fields there.
\end{abstract}

Keywords: Oil; Gas; Ural-African transcontinental oil-gas-bearing belt; Sedimentary basins; Oil-gas-bearing potential; Russia; Forecasting; Large petroleum fields

\section{Introduction}

Conventional hydrocarbon fields are currently being depleted throughout the world. Oil and gas are becoming ever more difficult to access. More and more, the operations of oil and gas companies are aimed offshore.

The globalization of the world economy is having a strong impact on raw materials markets, and these trends will intensify:

- The influence of raw materials resources on the economic stability of many countries will increase;

- Global transnational oil and gas companies will be less dependent on one government; they are already a mechanism for the rapid introduction of innovative technologies and are supporting economic progress in the developing nations;

- Political and economic risks will increase in those regions where there are plans to increase oil production, especially in the Caspian, Venezuela and West Africa;

- Middle Eastern oil supplying nations are becoming more and more unstable;

- Nations that produce raw materials claim to be liberalizing their foreign trade policy, but in practice are limiting access to their fields;

- Competition in the sphere of energy resources is increasing, and this is accompanied by problems in deliveries of resources to not only individual consumers, but even entire regions.

Therefore, the geographical extent of hydrocarbon resource exploration and development can be expanded in new geological provinces using new knowledge in the sphere of the geological structure and scientific and technical advances.

This paper is a continuation of the research at the National Mineral Resources University (University of Mines) that was described in the 'Geological Atlas of Russia [1-3].

\section{Oil and Gas Basins of the Earth}

Hydrocarbon fields below the Earth's surface are distributed extremely irregularly in geological space and in time. More than 226 oil and gas bearing sedimentary basins have now been discovered on Earth, in which approximately 50,000 crude hydrocarbon fields with proven oil reserves of 152 billion tonnes have been discovered. However, only a few of the basins (the Persian Gulf, West Siberia, Volga-Ural, Timan-Barents Sea, Mexican and Mediterranean basins) have reliably estimated reserves exceeding 2-5 billion tonnes. The total proven oil reserves in these six basins represent roughly $80 \%$ (120 billion tonnes) of total world reserves, while the other 220 basins contain only $20 \%$ (32 billion tonnes) [4-6].

Of the vast number of oil fields, the majority of the reserves $(>80 \%)$ are also concentrated in a small number of large and unique targets, the

*Corresponding author: Aleksandr Kozlov, Professor, Head of Department, Doctor of Geological and Mineralogical Sciences, University of Mines, Russia Tel: 7-812-328-82-57; E-mail: akozlov@spmi.ru

\section{Received March 22, 2014; Accepted May 29, 2014; Published June 06, 2014}

Citation: Litvinenko VS, Kozlov AV (2014) The Ural-African Transcontinental Oil and Gas Belt. J Pet Environ Biotechnol 5: 174. doi:10.4172/2157-7463.1000174

Copyright: (c) 2014 Litvinenko VS, et al. This is an open-access article distributed under the terms of the Creative Commons Attribution License, which permits unrestricted use, distribution, and reproduction in any medium, provided the original author and source are credited. 
Citation: Litvinenko VS, Kozlov AV (2014) The Ural-African Transcontinental Oil and Gas Belt. J Pet Environ Biotechnol 5: 174. doi:10.4172/21577463.1000174

Page 2 of 6

\begin{tabular}{|c|c|c|c|}
\hline \multirow{2}{*}{ Area } & \multicolumn{2}{|c|}{ Oil reserves } & \multicolumn{2}{|c|}{ Natural gas reserves } \\
\cline { 2 - 4 } & billion tonnes & \% of world reserves & trillion $\mathbf{m}^{\mathbf{3}}$ \\
\hline Entire planet & 152 & 100 & 149.3 \\
\hline Ural-African oil and gas belt & 110.3 & 74 & 96.3 \\
\hline Including oil and gas basins: Persian Gulf & 92.6 & 60.9 & 44.4 \\
\hline West Siberian & 12.0 & 8 & 30 \\
\hline
\end{tabular}

Table 1: Proven oil reserves (category $A+B+C_{1}$ ) worldwide and in the sedimentary basins of the Ural-African oil and gas belt.

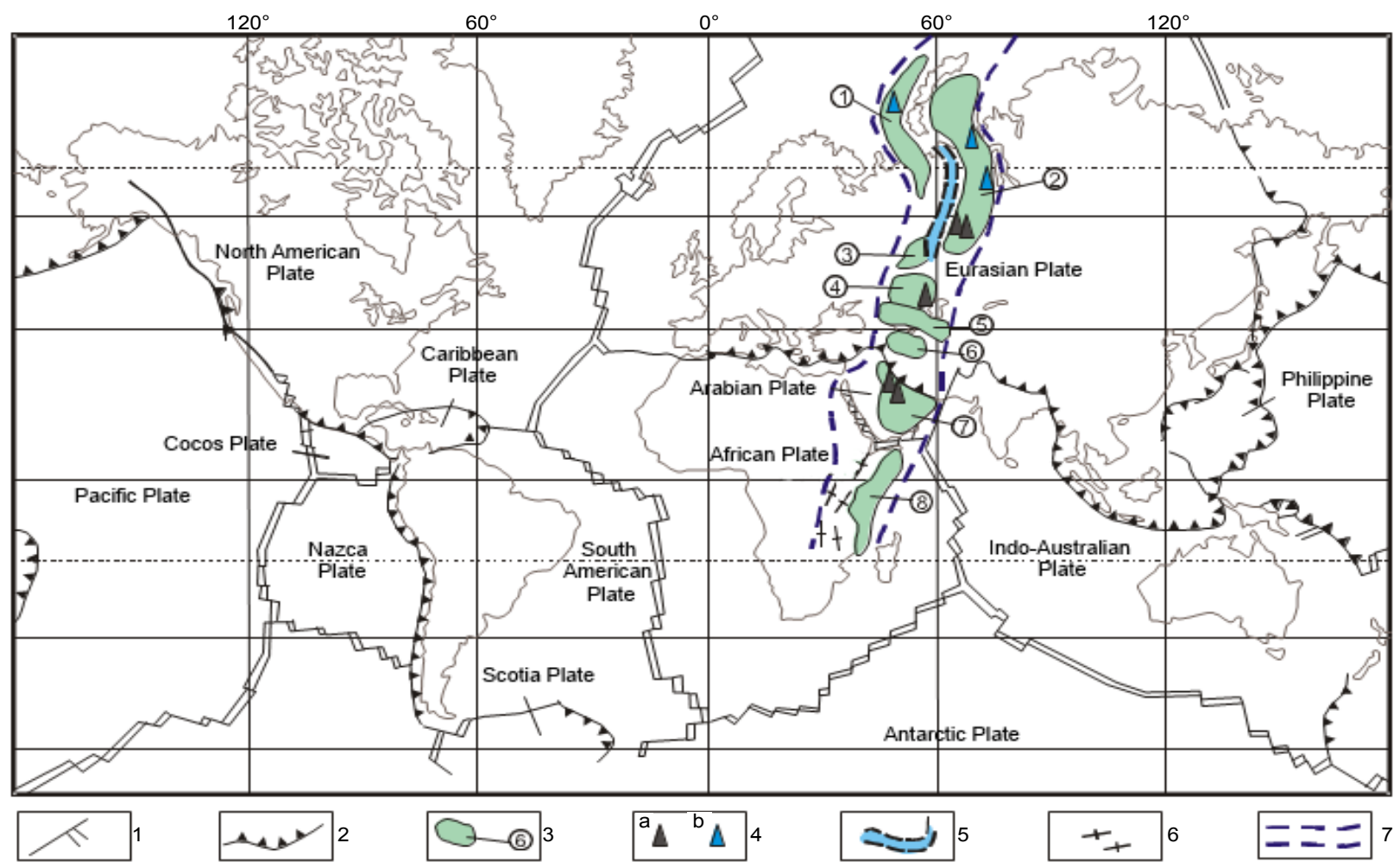

Figure 1: Position of transcontinental oil and gas belt in which $70-75 \%$ of total world oil reserves and more than $75 \%$ of world gas reserves are concentrated, in diagram of lithospheric plates.

1-oceanic rifts and transform faults; 2-boundaries of lithospheric plates in subduction and collision zones; 3-sedimentary basins with proven oil and gas presence: (figures in circles): 1-Timan-Barents Sea, 2-West Siberian, 3-Volga-Ural, 4-Caspian, 5-Western flank of Amu Darya, 6-South Caspian, 7-Persian Gulf, 8-East African (poorly studied); 4-primary regions with extensive unique oil (a) and gas (b) fields; 5-position of Ural riftogenic system; 6-fragments of East African Rift;

7-boundary of level of Earth gravitational potential (boundary of transition from decompressed abyssal masses of mantle to denser masses).

overwhelming majority of which are concentrated in two unique oil and gas basins (the Persian Gulf and West Siberian basins) and four large basins. The regions of maximum accumulation of crude hydrocarbons are associated with the stratigraphic levels of two geological eras: the Mesozoic (72\%) and Middle-Late Paleozoic (22\%). Due to this clearly pronounced irregularity in the concentrations of oil and gas fields in geological space and time, a minerogenic forecast analysis of oil and gas presence must be performed with consideration of the particular features of the locations of the largest oil and gas bearing sedimentary basins in Russia and worldwide.

Analysis of the location of oil and gas bearing sedimentary basins in parts of the world with various geological structures, geodynamic conditions, and evolution of material transformation shows that the majority of oil reserves (approximately 75\%) and gas reserves (approximately 65\%) discovered worldwide are concentrated in a meridional belt running from north to south along the western and eastern margins of the Novaya Zemlya and Ural fold systems through the Caspian and Persian Gulf sedimentary basins, and then along the
East African Rift system to the latitude of Madagascar (Table 1 and Figure 1). This structure, with a unique concentration of oil and gas fields ( $\sim 3 / 4$ of world reserves) and area of only $6-7 \%$ of the area of the entire globe, can be called the Ural-African transcontinental oil and gas belt. Practically all unique gigantic oil and gas fields (the Gwahar and Greater Burgan fields and the Samotlor, Urengoy, Shtokman and other fields in Russian territory) are located in it.

Proven oil reserves (category $\mathrm{A}+\mathrm{B}+\mathrm{C}_{1}$ ) worldwide and in the sedimentary basins of the Ural-African oil and gas belt [7-9]

\section{GeologicalStructure of the Ural-African Transcontinental Oil and Gas Bearing Belt}

The position of the Ural-African transcontinental oil and gas bearing belt can be explained by the features of the geological development, abyssal structure and geodynamics of the Earth in the near-meridional belt of the gigantic continental faulting (riftogenesis zone) in the central part of the Eurasian continent that lasted for a significant time in the 

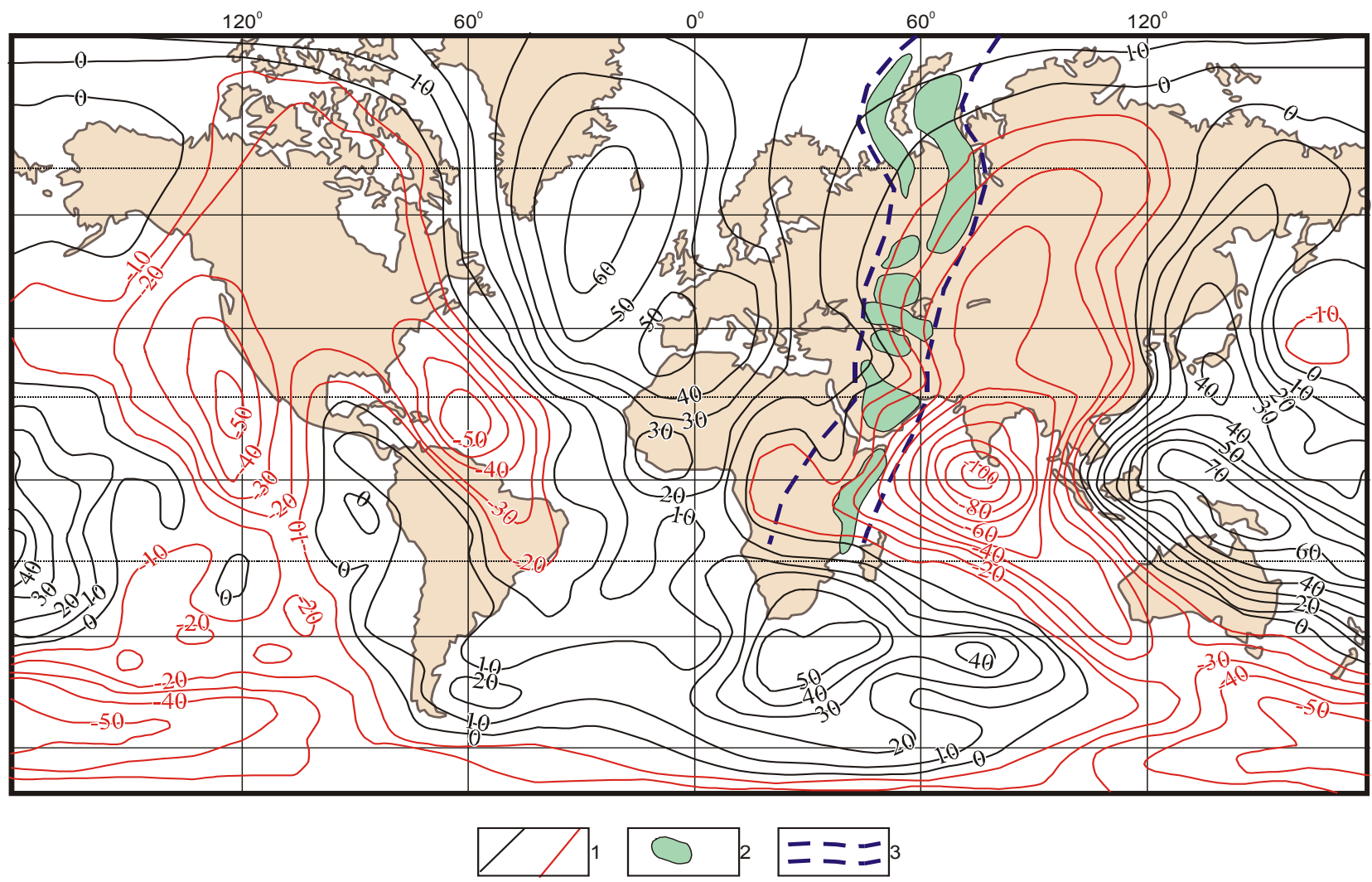

Figure 2: Association of transcontinental belt where there is elevated oil and gas presence with global level of Earth gravitational potential.

1-gravitational potential isolines (a-positive values, b-negative values); 2-sedimentary basins with proven oil and gas presence; 3-boundaries of transition (level) of Earth gravitational potential from decompressed abyssal masses of mantle to denser masses.

Paleozoic and Mesozoic, which continued with gradual regeneration in the southern Caspian, the Persian Gulf and the continent of Africa (the system of meridional African rifts).

The origin of the largest continental riftogenesis belt on Earth transversing the Dniepr-Donets aulacogen, the Mediterranean mobile belt and the Red Sea oceanic rift may be associated with the presence of inhomogeneities in the structure and composition of the abyssal subcrustal zones (apparently in the lower and upper mantle) in this part of the world. This inhomogeneity in the geological structure and the nature of the differentiation of the abyssal mantle and crustal masses is manifested as a global anomaly in the field of the Earth's gravitational potential that reflects the in homogeneities in their composition and density.

As can be seen in Figure 2, the oil and gas belt discovered is associated with the global gravitational potential level [1-3], which follows the relatively narrow (on the global scale) belt between the decompressed mantle rocks in the eastern zone of the Eurasian continent (east of the Urals) and the dense abyssal masses west of it. Processes of riftogenesis (stretching) of the crust along this level led not only to the formation of thick sedimentary basins, but also to intensive heat and mass transfer, which was accompanied by heating of the sedimentary source rocks and conversion of organic matter into liquid and gaseous hydrocarbons.

The development of the global continental riftogenesis system that runs meridionally across two continents was accompanied by the formation of lithospheric geodynamic systems with unique geological structure and minerals, the largest of which are:
- The zone of Ural Early-Middle Paleozoic continental spreading, which was accompanied by accumulation of thick sedimentary and sedimentary-igneous strata, intensive mantle-crust differentiation of material, intrusion of a wide range of igneous rocks, extensive manifestation of tectonic-metamorphic differentiation processes and formation of the unique Ural ore belt;

- Foredeeps (the pre-Ural foredeep and others) with formation of thick sedimentary strata and an extensive mineral complex (crude hydrocarbons, coals, salts, bauxites, etc.);

- Riftogenic oil and gas bearing sedimentary basins with the thickest sedimentary strata on the planet (up to $15-20 \mathrm{~km}$ thick) within deep uncompressed depressions-polygonal fault structures (the Caspian and Kara) and numerous rifts and aulacogens both in the cover of the recent West Siberian platform and the eastern part of the ancient Russian platform, as well as in the Arabian platform (the Mesopotamian depression) and along the east coast of Africa.

The riftogenesis processes in the transcontinental oil and gas belt began in the Late Riphean-Vendian and Early Paleozoic, when the Ural fault, the Novaya Zemlya depression and probably the Caspian deep uncompressed depression were formed [10]. Later, in the Late Paleozoic and Mesozoic, riftogenesis processes (without significant magmatism) covered the structure of the platforms around and within the continents (the East Eurasian, West Siberian and Barents Sea platforms) adjacent to the Urals and Novaya Zemlya. 
North and south of the Ural fold system and the Caspian basin, riftogenesis processes developed in later eras (the Mesozoic on the Arctic shelf and the Cenozoic within the Arabian Peninsula and the continent of Africa). Recent riftogenic structures in the Ural-African transcontinental belt occupy a position transversal to the oceanic rifts (in the Arctic Ocean, Red Sea and recent Mediterranean belt). As certain researchers [11] note, these were not associated with the development of recent oceanographic depressions and collisional structures in the zone of collision of the continental plates. The Ural continental fault and the fold system that appeared at the site of it played a special role in the formation of this independent global structure.

The Ural fold zone is heterogeneous through the deep structure of the Earth crust, and three most contrasting longitudinal linear regions can be distinguished in it [12]:

- The western region, which includes the margin of the East European platform, the Pre-Ural foredeep, the West Ural outer folding zone and the Central Ural uplift, which is bounded on the east by the Main Ural deep fault;

- The central region, corresponding in a first approximation to the Tagil-Magnitogorsk depression;

- The eastern zone-the East Ural uplift and the margin of the West Siberian platform.

The comparative description of the crust in these regions provided in $[12,13]$ indicates that the riftogenic structure of the Urals was formed and later developed in continental type crust with a thickness of 30-50 $\mathrm{km}$.

The beginning of the appearance of riftogenic processes dates back to the Late Riphean, when the East European-Siberian platform moved apart along a submeridional rift, creating the intracontinental rift. With manifestations of ultrabasic and basic magmatism, this period was associated with chromite (Saranovsk) and titanium-magnetite (Kusinsk-Kopansk) mineralization, respectively. With extensive manifestation of acid magmatism primarily in the Central Ural uplift, this period is associated with many gold, tungsten, molybdenum and polymetal fields. On the threshold of this process, activation of the marginal platform structures with formation of syndepositional depressions occurred in the Early Riphean, in which fields of siderite iron ore (the Bakalskaya group) and magnesite (the Satkinskaya group) were formed $[10,13,14]$.

The increase in tectonic activity in the Early Paleozoic led to an increase in the rate of formation of the fault and the formation of volcanic belts in the Tagil-Magnitogorsk depression, which in many respects are similar to island arc structures. However, according to geophysical data, the preservation of a granite-gneiss layer in this block makes it possible to classify the structure occurring during this process as an intracontinental rift. The significant increase in the crustal basicity coefficient within it is the result of the intrusion of significant volumes of basic and ultrabasic magmas, which led to a significant change in the metallogenic specialization of the region of the Ural fold belt. Large and unique chromite and platinum fields, pyrites of igneous and sedimentary origin, magmatic fields of iron-titanium-vanadium ores, etc. appeared widely in it. Primarily fields of nonmetallic minerals and stratiform fields of copper and polymetals were formed in the western region during this period.

The eastern part of the Ural belt occupies an intermediate position in terms of the crustal structure: the granite-gneiss layer was preserved in it, but it was intensively transformed by tectonic and magmatic processes, with the appearance of alternating longitudinal zones of riftogenic depressions and uplifts separating them, which caused intensive appearance of a wide range of magmatites within it Their combination in space and specific alternation in time led to the formation of diverse fields of metallic and nonmetallic minerals (gold, silver, tungsten, molybdenum, beryllium, iron [skarn fields], asbestos, talc, quartz crystal, etc.).

On the whole, the Ural fold system is unique in its mineralogenic potential, in the diversity of the lithophile, chalcophile and siderophile metallic minerals, in the presence of many types of nonmetallic raw materials (precious stones, salts, etc.), and in the extensive development of large and unique fields. There is no other system in the world with such scales and range of metallogenic specialization. The Ural structural metallogenic zone is exceptional because the long process of its active development with the formation of a meridional fault and subsequent metamorphism and folding initiated the formation of polygonal and linear riftogenic structures with exceptionally high oil and gas content on its flanks and in the continuation of the Urals $[10,11,13,14]$. Therefore, the Urals can be viewed not only as an independent structural geological and metallogenic province, but also as the axial zone of the wider and longer Ural-African transcontinental belt. Crustal-mantle interaction processes with extensive development of magmatism and fluid-hydrothermal activity appeared most actively and were most concentrated in the Ural fold zone, while on its margins, under conditions of more scattered crust-mantle heat and mass transfer with a lower gradient, deep sedimentary basins and oil and gas fields were formed.

\section{Prospects for the Detection of Large Hydrocarbon Fields in the Russian Part of the Ural-African Transcontinental Oil and Gas Bearing Belt}

A significant portion of the Ural-African transcontinental oil and gas belt ( $>50 \%$ of its area) is located in Russian territory. The primary sedimentary oil and gas basins in Russia are located in its northern part, in which the overwhelming majority of large and unique hydrocarbon fields containing the majority of the proven oil reserves (95\%) and gas reserves (>95\%) are located (Figures 2 and 3 ).

The largest proven reserves and 13 of the 14 unique oil fields and the primary natural gas reserves are found east of the Urals, in the West Siberian basin. Eleven regions are distinguished in the West Siberian oil and gas basin, which is collocated with the recent West Siberian platform and extends into the Kara Sea shelf. Two of these (the Middle $\mathrm{Ob}$ and Frolov provinces) are significantly petroliferous, three (the Gydan, Yamal and Pur-Tazov provinces) are gas-bearing, and the others are mixed.

The West Siberian basin is comparable to the Persian Gulf basin in terms of its extent and the thickness of the sedimentary cover, but significantly (is 8 times less) inferior to it in terms of oil reserves.

As is known, there is certain parity in the oil and gas reserves in the primary oil and gas basins worldwide [4,5]. Relying on this empirical law, the disproportion seen in the ratio of oil and gas reserves in West Siberia can be viewed as a strong argument for a high probability of discovering new, large oil fields here.

At present, nearly all oil reserves in West Siberia are located in the relatively small Middle $\mathrm{Ob}$ site (the Middle $\mathrm{Ob}$ and Frolov oil and gas provinces), where the primary unique fields are located, and the presence of oil in this territory as a whole has only been studied fragmentally and irregularly. The near-meridional riftogenic structures 


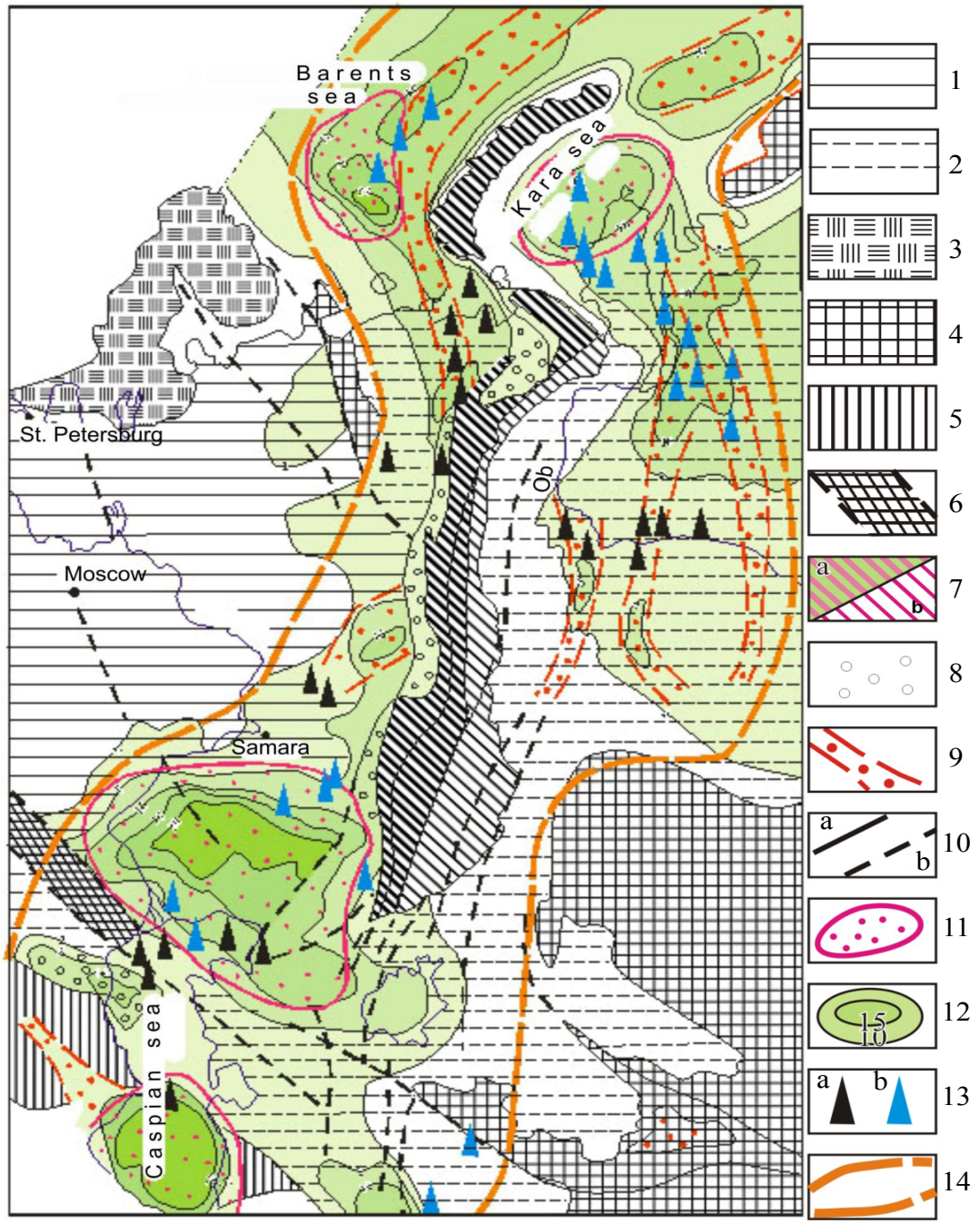

Figure 3: Northern fragment of Ural-African intensive riftogenesis belt.

1-4-Stabilized crustal blocks (cover and platform basement): 1-cover of ancient platforms (PZ, MZ); 2-cover of recent platforms (PZ-MZ); 3-Pre-Cambrian fold regions; 4-Phanerozoic fold regions; 5-6-Mobile regions: 5-basement of Mediterranean orogenic belt; 6-eastern terminus of Dniepr-Donets rift; 7-10-zones and regions of intensive continental riftogenesis: 7-linear suture zones with intensive sedimentation (a), mantle magmatism (b) and subsequent folding (Ural-Novaya Zemlya fold system); 8-foredeeps with intensive extension and downwarping; 9-linear riftogenesis (rift) zones; 10-faults: a-proven, b-assumed; 11-regions of polygonal riftogenesis; 12-thickness of sedimentary deposits; 13-oil (a) and gas (b) fields; 14-approximate boundary of Ural-African intercontinental belt.

extending northward from the central part of the platform are of special interest. The largest oil-gas, gas condensate and gas fields in the world have been discovered in these structures. It is very possible that prospecting for oil reservoirs in the riftogenic structures, including at depths below $3 \mathrm{~km}$, will make it possible to find the significant (more than 30 billion tonnes) inferred oil reserves in the West Siberian basin.

Four oil and gas basins are located west of the Ural-Novaya Zemlya fold system (Figure 3): the Caspian basin in the south, the Volga-Ural basin in the centre, and the Timan-Pechora basin in the north onshore and the Barents Sea basin offshore (the Timan-Pechora and Barents Sea basins might be viewed as a single basin). These two basins combined are very similar to the West Siberian oil and gas basin in terms of dimensions, tectonic structure, and zoning of the field distribution (primarily oil fields in the south and primarily gas fields in the north). However, the basins located west of the Urals and Novaya Zemlya differ significantly from the West Siberian basin in terms of the composition of the host rocks, their reservoir properties, the age of the oil bearing and source rocks and the types of traps (Figure 3 ).

In the West Siberian basin, the majority of the hydrocarbon reserves are associated with terrigenous Mesozoic rocks (oil is primarily in Jurassic-Early Cretaceous deposits, while gas is in Cretaceous and partially in Late Jurassic rocks) in anticlinal and lithologic traps. At present, insignificant oil reserves have been identified in more ancient Paleozoic deposits; this may be due to the poor study of the Paleozoic portion of the sedimentary cover. Oil and gas reservoirs in the Caspian, Volga-Ural, Timan-Pechora and Barents Sea basins are located in both terrigenous and carbonate rocks, and the age range of the primary pay zones is wider-from predominantly Late Paleozoic (primarily Devonian, Permian and Permian-Carboniferous) to Mesozoic (Triassic). In addition to anticlinal and lithologic traps, other types of traps associated with salt-bearing and reef complexes are widespread in these basins. The composition of the source rocks also differs 
slightly: Mesozoic carbonaceous shale formations predominate in the West Siberian basin; bituminous terrigenous and carbonate deposits, primarily from the Early and Middle Paleozoic, are found west of the Urals.

In addition, factors favourable for the formation of large and unique oil and gas fields are typical for all Russian basins in the Ural-African oil and gas belt:

- Significant thickness of sedimentary deposits, which is unique in the world, high sedimentation rates, extensive occurrence of rocks with abnormal content of Corg and complexes with good reservoir properties;

- Extensive occurrence of riftogenic structures of various ages and intensive fluid heat and mass transfer associated with riftogenesis, which heated the sedimentary strata and possibly carried in additional hydrocarbon gases from greater depths;

- The presence of complex of favourable structural, lithologic and other traps, as well as the occlusive strata necessary for the formation of oil and gas reservoirs;

- The favourable geodynamic factors (temperature, pressure, alternation of extension and compression processes, etc.).

The aggregate of these factors promoted the appearance in these basins of intensive, large-scale hydrocarbon accumulation and the formation of unique fields with a vertical pay zone range of hundreds of metres (the Samotlor and Romashkin fields and others).

These most promising sedimentary basins differ significantly in degree of exploration maturity and reserves development. In addition to the well-studied and developed oil and gas basins (the Volga-Ural basin and the southern part of the Timan-Pechora basin), significant areas of the West Siberian oil and gas basin, the northern part of the TimanPechora basin, the Barents Sea basin and the Caspian basin (especially the offshore zone and deep horizons) have clearly been insufficiently prospected, especially oil reconnaissance. There are some prospects for discovery of large and unique oil fields in the eastern part of the North Caucasus basin, which is in the Ural-African oil and gas belt, partially onshore (in Dagestan) and partially offshore in the Caspian Sea [15]. On the whole, the sedimentary basins noted above in the transcontinental oil and gas belt are the most promising for the discovery of profitable large and unique oil fields and oil and gas provinces both onshore and offshore in comparison to other sedimentary basins in the west and east of Russia. The primary research and geological surveying should be concentrated here in order to accelerate the replacement of reserves.

\section{Conclusions}

The analysis of identification of highly profitable reserves by discovering new large and unique oil fields in the most promising sedimentary basins in the oil and gas regions of Russia and worldwide has shown that the riftogenic structures west and east of the UralNovaya Zemlya fold system are the principal basins. Major oil basins (the West Siberian, Timan-Pechora, Volga-Ural basins, etc.) which are part of the northern branch of the Ural-African transcontinental oil and gas belt with the largest hydrocarbon reserves on Earth are located here. Successful realization of the predicted discovery of new and unique oil fields in these most important oil and gas bearing structures in Russia will require re-examination of previous research and geological survey plans. Compilation of 1:2,500,000 scale minerogenic forecast maps should serve as the basis for evaluation of oil and gas-bearing capacity of the largest Ural belt containing hydrocarbon basins, with subsequent development of short- and long-term plans for expansion of geological survey and drilling in this basin.

\section{References}

1. Geological Atlas of Russia (1995-1996) Sections 1,2; Editors Smyslov A Roskomnedra, Goskomvuz, Russian Academy of Sciences, Geokart Moscow St Petersburg: 40 maps.

2. Geological Atlas of Russia (1995-1996) Sections 1,2; Editors Smyslov A Roskomnedra, Goskomvuz, Russian Academy of Sciences, Geokart. Moscow St Petersburg: 20 maps.

3. Geological Atlas of Russia (1995-1996) Sections 1-4; Editors Smyslov A Roskomnedra, Goskomvuz, Russian Academy of Sciences, Geokart. Moscow St Petersburg: 5 volumes.

4. Masters CD, Root DH, Turner RM (1997) World resource statistics geared for electronic access. Oil Gas J 95

5. Carmalt SW, St. John B (1986) Giant Oil and Gas Fields. Future Petroleum Provinces of the World, AAPG Special Volumes 11-53.

6. Kontorovich AE (2009) Estimate of global oil resource and the forecast fo global oil production in the 21st century. Russian Geology and Geophysics 50 237-242.

7. Bezhanova M, Bezhanov C (2002) Reserves and production of major types of mineral raw materials of the World. VNIlzarubezhgeologia Moscow Russia.

8. Neftegazovye resources (2003) Special review. Expert 45: 96-104.

9. Reserves, Resources and Availability of Energy Resources (2002) Federal Ministry of Economics and Labour Russia.

10. Ivanov C, Koroteev V, Puchkov V, Ivanov K (1989) Evolution rift systems of the Urals. Tectonic processes, Reports of Soviet geologists XXVIII session of the international Congress Moscow Russia.

11. Surkov V (1998) Rifting and oil and gas basins of Siberia. Geology of oil and gas 10: 33-36

12. Berlyand N (1982) Division Ural-type structure of the earth crust. Sov Geologya 11: 78-89.

13. Popov V, Rapoport V (1996) Tectonic-magmatic development of the Urals: new aspects of the old problem. Proceedings of higher educational establishments. Geology and Exploration 4: 3-21.

14. Kovalev C (2008) Rifting and metallogeny (on the example of the Western slope of the South Urals). The geological collection of the Institute of Geology Ural scientific center of Russian Academy of Sciences 7: 68-87.

15. Volozh J, Dmitrievsky A, Leonov J, Militenko N, Rovnin L (2009) On the strategy of the next stage of oil exploration activities in the Caspian oil and gas province. Geology and Geophysics 4: 341-362. 